\title{
PEMANFAATAN CANGKANG TELUR AYAM BROILER SEBAGAI TEPUNG KERABANG UNTUK MENINGKATKAN UNSUR HARA PADA TANAMAN
}

Fanny Putri Andari, Koerniasari, Marlik*

Jurusan Kesehatan Lingkungan, Poltekkes Kemenkes Surabaya

*Email korespondensi: marlik2503@gmail.com

\begin{abstract}
ABSTRAK
Sampah merupakan bahan padat buangan yang berasal dari kegiatan rumah tangga, pasar, perkantoran, dll. Salah satunya adalah cangkang telur. Cangkang telur merupakan limbah sisa buangan dari dapur yang berpotensi untuk dimanfaatkan. Sampai saat ini, limbah cangkang telur belum dimanfaatkan secara maksimal. Tujuan dari penelitian ini yaitu pemanfaatan cangkang telur ayam broiler sebagai tepung kerabang untuk meningkatkan unsur hara pada tanaman bayam.

Jenis penelitian ini menggunakan eksperimen murni dengan menggunakan rancangan Posttest Only Control Group Design yang terdiri dari 6 perlakuan dengan konsentrasi yaitu $0 \%$ (kontrol), 20\%, 25\%, 30\%, 35\%, 40\%, dan 4 kali pengulangan. Penelitian dilakukan dengan mengukur pada parameter pertumbuhan tanaman bayam yaitu tinggi tanaman, jumlah daun, berat basah batang, berat basah akar, berat kering batang, dan berat kering akar yang dilakukan selama 3 minggu. Data yang diperoleh selanjutnya dianalisis secara analitik menggunakan uji kruskal wallis dan dilanjutkan dengan uji Post Hoc Mann Whitney $U$.

Hasil kandungan unsur hara N, P, K mengalami peningkatan seiring dengan meningkatnya konsentrasi. Hal tersebut berbeda dengan hasil pertumbuhan tanaman bayam. Pertumbuhan tanaman bayam menunjukkan hasil yang paling tinggi yaitu pada perlakuan $20 \%$. Hasil uji kruskal wallis menunjukkan pada konsentrasi berat tepung kerabang cangkang telur terhadap pertumbuhan tinggi tanaman dan berat basah tanaman. Hasil uji Post Hoc Mann Whitney $U$ terdapat perbedaan yang signifikan dari berbagai konsentrasi berat tepung kerabang cangkang telur terhadap pertumbuhan tanaman bayam $(\mathrm{P}<0,05)$.

Disimpulkan bahwa pada perlakuan $20 \%$ menunjukkan hasil yang dianjurkan untuk meningkatkan pertumbuhan tanaman bayam. Hal ini merupakan faktor lingkungan dan perawatan yang dapat mempengaruhi pertumbuhan tanaman bayam. Perlu dilakukan penelitian lebih lanjut dengan konsentrasi lebih rendah.
\end{abstract}

Kata Kunci : Sampah, cangkang telur, pupuk kompos, bayam

\section{PENDAHULUAN}

Seiring dengan meningkatnya jumlah penduduk di Indonesia dan berkembangnya waktu, maka kebutuhan pangan semakin meningkat. Sampah merupakan bahan padat buangan dari kegiatan rumah tangga, pasar, perkantoran, rumah penginapan, hotel, rumah makan, industry, dan puingan bahan bangunan. Di kota Surabaya, banyak terdapat toko roti, rumah makan, martabak telur yang menggunakan telur sebagai bahan bakunya, sehingga masih banyak limbah kulit/cangkang telur yang dibuang begitu saja tanpa ada pemanfaatan atau pendaurulangan cangkang telur tersebut. Apabila limbah tersebut tidak ditangani dengan benar, maka akan menimbulkan dampak pada pencemaran lingkungan (Emi, 2014).

Cangkang telur merupakan limbah sisa buangan dari dapur yang berpotensi untuk dimanfaatkan. Sampai saat ini, limbah cangkang telur belum dimanfaatkan secara maksimal. Cangkang telur hanya digunakan sebagi produk kerajinan tangan. Menurut Nurshanti (2009) cangkang telur dapat dijadikan sebagai pupuk organik. Dari hasil laboratorium (Lampiran 6) bahwa cangkang telur memiliki kandungan kalsium karbonat $(15,38 \%)$, fosfor $(0,41 \%)$, natrium $(0,095 \%)$, kalsium $(0,056 \%)$, protein $(3,08 \%)$, kadar air $(0,33 \%)$, dan nitrogen $(0,09 \%)$. 
Kandungan-kandungan tersebut dibutuhkan oleh tanaman. Salah satunya adalah tanaman bayam. Bayam (Amaranthus tricolor L.) merupakan tanaman yang dapat dikonsumsi sebagai sayuran. Kandungan serat dari tanaman bayam cukup tinggi sehingga dapat membantu memperlancar proses pencernaan. Bayam juga mengandung beberapa macam vitamin, seperti vitamin A, B, dan C (Irma, 2015).

Unsur hara $\mathrm{N}$, $\mathrm{P}$ dan $\mathrm{K}$ merupakan unsur hara yang sangat penting peranannya bagi pertumbuhan tanaman. Menurut pendapat Hardjowigeno (2007), menyatakan bahwa unsur hara esensial sangat diperlukan oleh tanaman dan fungsinya dalam tanaman tidak dapat digantikan oleh unsur lain. Menurut Isniati (2009) menyatakan bahwa unsur hara dalam hasil pupuk kompos dengan penambahan tepung cangkang telur menghasilkan unsur hara dengan presentase rata-rata $\mathrm{N}, \mathrm{P}, \mathrm{K}$ yaitu $\mathrm{N}=$ $0,675 \%, P=49,553 \%$, dan $\mathrm{K}=$ $0,767 \%$.

\section{METODE PENELITIAN}

Penelitian ini bertujuan untuk mengetahui pemanfaatan cangkang telur ayam broiler sebagai tepung kerabang untuk meningkatkan unsur hara pada tanaman bayam. Penelitian ini dilakukan di jalan Semampir Tengah No. 39a pada tanggal 17 Februari - 10 Maret 2019. Penelitian ini dilakukan 6 kali perlakuan penanaman dengan cara melakukan pemberian konsentrasi $0 \%$ (kontrol), 20\%, 25\%, 30\%, 35\%, 40\% dan dilakukan 4 kali pengulangan dengan diaplikasikan ke tanaman bayam. Pertumbuhan tanaman bayam diteliti setiap harinya selama 3 minggu dengan penyiraman tanaman sebanyak 2 kali yaitu pagi dan sore hari. Penyiraman baik dilakukan pada pagi hari pukul 07.00-08.00 WIB dan sore hari pukul 16.00-18.00 WIB (Nurjanah. 2017). Pertumbuhan tanaman bayam yang diteliti adalah mengukur tinggi tanaman, jumlah daun, berat basah tanaman, berat basah akar, berat kering tanaman, dan berat kering akar. Analisis data yang digunakan dalam penelitian ini adalah uji kruskal wallis dan dilanjutkan dengan uji Post Hoc Mann Whitney $U$.

\section{HASIL DAN PEMBAHASAN}

1. Hasil Pemeriksaan Kandungan Unsur Hara $N$, $P$, dan $K$

Tabel 1

HASIL PEMERIKSAAN KANDUNGAN UNSUR HARA N, P, DAN K

\begin{tabular}{cccc}
\hline Dosis & $\begin{array}{c}\mathbf{N} \text { (Nitrogen) } \\
(\mathbf{\%})\end{array}$ & $\begin{array}{c}\mathbf{P} \text { (Fospor) } \\
(\mathbf{\%})\end{array}$ & $\begin{array}{c}\text { K (Kalium) } \\
(\%)\end{array}$ \\
\hline $0 \%($ kontrol) & 0,098 & 0,147 & 0,086 \\
\hline $20 \%$ & 2,85 & 0,56 & 1,27 \\
\hline $25 \%$ & 3,09 & 0,82 & 2,14 \\
\hline $30 \%$ & 3,31 & 0,93 & 3,98 \\
\hline $35 \%$ & 3,79 & 1,15 & 4,23 \\
\hline $40 \%$ & 4,22 & 1,22 & 5,17
\end{tabular}

Berdasarkan Tabel 1 dapat diketahui bahwa dari hasil pengukuran laboratorium untuk kandungan unsur hara $\mathrm{N}, \mathrm{P}$, dan $\mathrm{K}$ pada konsentrasi $0 \%$ (kontrol), 20\%, $25 \%$, 30\%, 35\%,dan $40 \%$ mengalami peningkatan. Untuk unsur hara $\mathrm{N}$ pada konsentrasi paling besar yaitu konsentrasi $40 \%$ sebesar $4,22 \%$. Untuk unsur hara $\mathrm{P}$ pada konsentrasi paling besar yaitu konsentrasi $40 \%$ sebesar 1,22\%. Untuk unsur hara $\mathrm{K}$ pada konsentrasi paling

besar yaitu konsentrasi $40 \%$ sebesar $5,17 \%$.

Pemberian pupuk N, $\mathrm{P}$, dan $\mathrm{K}$ memberikan pengaruh terhadap pertumbuhan tanaman bayam. Menurut Naswir (2008) unsur $N$ berfungsi dalam membantu pertumbuhan akar, sedangkan unsur $P$ berfungsi dalam mendorong pertumbuhan akar. Pada unsur $\mathrm{K}$ berperan membantu pemberian protein dan karbohidrat untuk meningkatkan kualitas biji/buah. 


\section{Pengukuran pH tanah, Suhu, dan Kelembaban}

Tabel 2

HASIL RATA-RATA PENGUKURAN pH TANAH

PADA SETIAP PERLAKUAN

\begin{tabular}{ccccccc}
\hline \multirow{2}{*}{ Replikasi } & \multicolumn{7}{c}{ Konsentrasi } \\
\cline { 2 - 7 } & $\mathbf{0 \%}$ & $\mathbf{2 0 \%}$ & $\mathbf{2 5 \%}$ & $\mathbf{3 0 \%}$ & $\mathbf{3 5 \%}$ & $\mathbf{4 0 \%}$ \\
\hline 1 & 6 & 7 & 6 & 6 & 6 & 6 \\
\hline 2 & 6 & 7 & 6 & 6 & 6 & 6 \\
\hline 3 & 6 & 7 & 7 & 7 & 6 & 6 \\
\hline 4 & 6 & 7 & 7 & 7 & 7 & 7 \\
\hline Minimal & 6 & 7 & 6 & 6 & 6 & 6 \\
\hline Maksimal & 6 & 7 & 7 & 7 & 7 & 7 \\
\hline Rata-rata & 6 & 7 & 6,5 & 6,5 & 6,25 & 6,25 \\
\hline Simpangan Baku & 0 & 0 & 0,6 & 0,6 & 0,5 & 0,5 \\
\hline
\end{tabular}

Berdasarkan data pada Tabel 2 dapat diketahui bahwa dari hasil pengukuran $\mathrm{pH}$ tanah yang paling besar yaitu pada konsentrasi $20 \%$ dengan $\mathrm{pH}$ rata-rata 7 . Kualitas media tanam bayam yang baik memiliki $\mathrm{pH}$ tanah 6-7 (Sumarni, 2007). Keadaan ini yang merupakan salah satu faktor sehingga tanaman dapat tumbuh pada tanah yang diberikan perlakuan yang mendekati $\mathrm{pH}$ ideal. Menurut Haryanto,dkk (2003) Keadaan inilah yang sangat dibutuhkan oleh tanaman untuk tumbuh.

Tabel 3

HASIL PENGUKURAN SUHU UDARA DAN KELEMBABAN SELAMA 3 MINGGU

\begin{tabular}{lcc}
\hline & Suhu $\left({ }^{\circ} \mathbf{C}\right)$ & Kelembaban $(\%)$ \\
\hline Minimal & 28 & 80 \\
\hline Maksimal & 32 & 82 \\
\hline Rata-rata & 29,6 & 81,3 \\
\hline Simpangan Baku & 1,47 & 0,97
\end{tabular}

Berdasarkan data pada Tabel 3 dapat diketahui bahwa dari hasil pengukuran suhu udara yang dilakukan selama 3 minggu memiliki rata-rata $29,6^{\circ} \mathrm{C}$. Sedangkan hasil kelembaban memiliki rata-rata $81,3 \%$. Kebutuhan sinar matahari untuk tanaman bayam cukup tinggi dengan pertumbuhan optimum pada suhu udara berkisar 17$28^{\circ} \mathrm{C}$, serta kelembaban udara $50-60 \%$ (Lestari, 2009).

3. Pengukuran Pada Tanaman Bayam

a. Tinggi Tanaman

Tabel 4

HASIL PENGUKURAN TINGGI TANAMAN (CM) TANAMAN BAYAM PADA AKHIR MINGGU KE 3

\begin{tabular}{|c|c|c|c|c|c|c|}
\hline \multirow[b]{2}{*}{ Replikasi } & \multicolumn{6}{|c|}{ Konsentrasi } \\
\hline & $0 \%$ & $\begin{array}{l}20 \\
\%\end{array}$ & $\begin{array}{l}25 \\
\% \\
\end{array}$ & $\begin{array}{l}30 \\
\% \\
\end{array}$ & $\begin{array}{l}35 \\
\%\end{array}$ & $40 \%$ \\
\hline 1 & 4 & 8,7 & 3,7 & 3 & 3,3 & 4 \\
\hline 2 & 4 & 9,6 & 4 & 4,5 & 3,1 & 3,2 \\
\hline 3 & 2,9 & 5,5 & 3,2 & 5,1 & 3 & 3 \\
\hline 4 & 3,5 & 5,2 & 4,6 & 3,1 & 2,9 & 3,1 \\
\hline Minimum & 2,9 & 5,2 & 3,2 & 3 & 2,9 & 3 \\
\hline Maksimum & 4 & 9,6 & 4,6 & 5,1 & 3,3 & 4 \\
\hline Rata-rata & 3,6 & 7,25 & 3,9 & 3,9 & 3,08 & 3,3 \\
\hline Simpangan Baku & 0,52 & 2,23 & 0,59 & 1,04 & 0,17 & 0,46 \\
\hline
\end{tabular}


Berdasarkan data pada Tabel 4 dapat diketahui bahwa dari hasil pengukuran tinggi tanaman bayam yang ditanaman selama 3 minggu memiliki hasil yang paling tinggi yaitu pada konsentrasi $20 \%$ dengan hasil rata-rata $7,25 \mathrm{~cm}$. Tinggi tanaman merupakan salah satu tolak ukur untuk mengetahui pengaruh pupuk tersebut pada tanaman. Nitrogen adalah komponen utama dari berbagai substansi penting di dalam tanaman. Nitrogen dibutuhkan dalam jumlah relatif besar pada setiap

\section{b. Jumlah Daun}

pertumbuhan tanaman, khususnya pada tahap pertumbuhan vegetatif, seperti pembentukan tunas atau perkembangan batang dan daun. Jika tanaman kekurangan nitrogen maka tanaman akan mengalami pertumbuhan yang lambat dan kerdil (Novizan, 2005). Akan tetapi nitrogen dengan jumlah terlalu banyak dapat mengahambat pertumbuhan dan pembuahan pada tanaman (Sutejo, 2002).

Tabel 5

HASIL PENGUKURAN JUMLAH DAUN (HELAI) TANAMAN BAYAM PADA AKHIR MINGGU KE 3

\begin{tabular}{ccccccc}
\hline \multirow{2}{*}{ Replikasi } & \multicolumn{7}{c}{ Konsentrasi } \\
\cline { 2 - 7 } & $\mathbf{0 \%}$ & $\mathbf{2 0}$ & $\mathbf{2 5}$ & $\mathbf{3 0}$ & $\mathbf{3 5}$ & \multirow{2}{*}{$\mathbf{4 0 \%}$} \\
\hline 1 & 3 & 5 & 2 & 3 & 3 & 3 \\
\hline 2 & 3 & 4 & 3 & 3 & 2 & 2 \\
\hline 3 & 3 & 3 & 2 & 2 & 2 & 2 \\
\hline 4 & 2 & 3 & 3 & 2 & 3 & 3 \\
\hline Minimum & 2 & 3 & 2 & 2 & 2 & 2 \\
\hline Maksimum & 3 & 5 & 3 & 3 & 3 & 3 \\
\hline Rata-rata & 2,75 & 3,75 & 2,5 & 2,5 & 2,5 & 2,5 \\
\hline Simpangan Baku & 0,5 & 0,96 & 0,58 & 0,58 & 0,58 & 0,58 \\
\hline
\end{tabular}

Berdasarkan data pada Tabel 5 dapat diketahui bahwa dari hasil jumlah daun yang diukur pada akhir minggu ke 3 menggunakan mistar (penggaris) memiliki hasil yang paling tinggi yaitu

\section{c. Berat basah Tanaman}

pada konsentrasi $20 \%$ dengan hasil rata-rata 3,75 helai. Semakin tinggi suatu tanaman maka semakin tinggi jumlah daun yang dihasilkan.

Tabel 6

HASIL PENIMBANGAN BERAT BASAH (GRAM) TANAMAN BAYAM PADA AKHIR MINGGU KE 3

\begin{tabular}{ccccccc}
\hline \multirow{2}{*}{ Replikasi } & \multicolumn{7}{c}{ Konsentrasi } \\
\cline { 2 - 7 } & $\mathbf{0 \%}$ & $\mathbf{2 0 \%}$ & $\mathbf{2 5 \%}$ & $\mathbf{3 0 \%}$ & $\mathbf{3 5 \%}$ & $\mathbf{4 0 \%}$ \\
\hline 1 & 0,018 & 0,027 & 0,011 & 0,018 & 0,011 & 0,012 \\
\hline 2 & 0,013 & 0,079 & 0,022 & 0,025 & 0,009 & 0,011 \\
\hline 3 & 0,009 & 0,024 & 0,009 & 0,011 & 0,009 & 0,009 \\
\hline 4 & 0,010 & 0,026 & 0,023 & 0,011 & 0,013 & 0,013 \\
\hline Minimum & 0,009 & 0,024 & 0,009 & 0,011 & 0,009 & 0,009 \\
\hline Maksimum & 0,018 & 0,079 & 0,023 & 0,025 & 0,013 & 0,013 \\
\hline Rata-rata & 0,013 & 0,039 & 0,016 & 0,016 & 0,01 & 0,011 \\
\hline Simpangan Baku & 0,004 & 0,027 & 0,0073 & 0,0067 & 0,0019 & 0,0017 \\
\hline
\end{tabular}

Berdasarkan data pada Tabel 6 dapat diketahui bahwa dari hasil penimbangan berat basah tanaman bayam pada akhir minggu ke 3 mendapatkan hasil yang paling tinggi yaitu pada konsentrasi $20 \%$ dengan hasil rata-rata 0,039 gram. Pertumbuhan berat basah tanaman 
dipengaruhi oleh unsur hara yang didapat meningkatan berat basah tanaman bayam. Kalsium merupakan faktor dalam sintesis protein, mengatur keseimbangan air, dan membuka menutupnya stomata (Jovita, 2018).

\section{d. Berat Basah Akar}

\section{Tabel 7}

HASIL PENIMBANGAN BERAT BASAH AKAR (GRAM) TANAMAN BAYAM PADA AKHIR MINGGU KE 3

\begin{tabular}{ccccccc}
\hline \multirow{2}{*}{ Replikasi } & $\mathbf{0 \%}$ & $\mathbf{2 0 \%}$ & $\mathbf{2 5 \%}$ & $\mathbf{3 0 \%}$ & $\mathbf{3 5 \%}$ & $\mathbf{4 0 \%}$ \\
\cline { 2 - 7 } & 0,003 & 0,027 & 0,001 & 0,002 & 0,001 & 0,003 \\
\hline 1 & 0,003 & 0,039 & 0,008 & 0,009 & 0,005 & 0,006 \\
\hline 2 & 0,005 & 0,008 & 0,005 & 0,007 & 0,006 & 0,006 \\
\hline 3 & 0,006 & 0,009 & 0,007 & 0,005 & 0,003 & 0,003 \\
\hline 4 & 0,003 & 0,008 & 0,001 & 0,002 & 0,001 & 0,003 \\
\hline Minimum & 0,006 & 0,039 & 0,008 & 0,009 & 0,006 & 0,006 \\
\hline Maksimum & 0,0043 & 0,02 & 0,0053 & 0,0058 & 0,0038 & 0,0045 \\
\hline Rata-rata & 0,0015 & 0,015 & 0,003 & 0,003 & 0,0022 & 0,0017 \\
\hline
\end{tabular}

Berdasarkan data pada Tabel 7 dapat diketahui bahwa dari hasil penimbangan berat basah tanaman bayam pada akhir minggu ke 3 mendapatkan hasil yang paling tinggi yaitu pada konsentrasi $20 \%$ dengan hasil rata-rata 0,02 gram. Menurut Sitompul dan Guritno (1995) peranan

\section{e. Berat Kering Tanaman}

Tabel 8

HASIL PENIMBANGAN BERAT KERING

(GRAM) TANAMAN BAYAM PADA AKHIR MINGGU KE 3

\begin{tabular}{|c|c|c|c|c|c|c|}
\hline \multirow{2}{*}{ Replikasi } & \multicolumn{6}{|c|}{ Konsentrasi } \\
\hline & $0 \%$ & $20 \%$ & $25 \%$ & $30 \%$ & $35 \%$ & $40 \%$ \\
\hline 1 & 0,003 & 0,011 & 0,001 & 0,001 & 0,001 & 0 \\
\hline 2 & 0,001 & 0,007 & 0,002 & 0,004 & 0,001 & 0,002 \\
\hline 3 & 0,001 & 0,001 & 0,001 & 0,002 & 0,002 & 0,002 \\
\hline 4 & 0 & 0,002 & 0,006 & 0 & 0 & 0,003 \\
\hline Minimum & 0 & 0,001 & 0,001 & 0 & 0 & 0 \\
\hline Maksimum & 0,003 & 0,011 & 0,006 & 0,004 & 0,002 & 0,003 \\
\hline Rata-rata & 0,0013 & 0,005 & 0,0025 & 0,0018 & 0,001 & 0,0018 \\
\hline Simpangan Baku & 0,0013 & 0,0046 & 0,0024 & 0,0017 & 0,0008 & 0,0013 \\
\hline $\begin{array}{l}\text { Berdasarkan d } \\
\text { dapat diketahui b } \\
\text { penimbangan berat } \\
\text { bayam pada akhir } \\
\text { mendapatkan hasil } \\
\text { yaitu pada konsent } \\
\text { hasil rata-rata } 0,00 \\
\text { Dianita dan Abdull } \\
\text { menyatakan bahwa pe }\end{array}$ & $\begin{array}{l}\text { pada Tà } \\
\text { a dari } \\
\text { Isah tar } \\
\text { inggu } \\
\text { paling } \\
20 \% \text { d } \\
\text { ram. M } \\
\text { (2011) } \\
\text { mbuhan }\end{array}$ & & $\begin{array}{l}\text { daun da } \\
\text { kering ta } \\
\text { Pengam } \\
\text { digunak } \\
\text { menghir } \\
\text { akibat k } \\
\text { merata } \\
\text { tanamar } \\
\text { pengam } \\
\text { dan }\end{array}$ & $\begin{array}{l}\text { batang } \\
\text { aman. } \\
\text { an berat } \\
\text { dari } \\
\text { ari kerac } \\
\text { ndungan } \\
\text { iantara } \\
\text { dari pe } \\
\text { an yang } \\
\text { Gurit }\end{array}$ & $\begin{array}{l}\text { mpengar } \\
\text { kering I } \\
\text { rat seg } \\
\text { man be } \\
\text { daun y } \\
\text { dividu d } \\
\text { kuan di } \\
\text { eerbeda }\end{array}$ & $\begin{array}{l}\text { hi bobot } \\
\text { oih baik } \\
\text { untuk } \\
\text { a daun } \\
\text { ng tidak } \\
\text { un atau } \\
\text { waktu } \\
\text { Sitompul } \\
\text { 1995). }\end{array}$ \\
\hline
\end{tabular}

akar dalam pertumbuhan tanaman yaitu menyediakan unsur hara dan air yang diperlukan dalam metabolisme tanaman. Menurut Suhartina, dkk (2013) fosfor merangsang pertumbuhan akar, khususnya akar benih atau tanaman muda.
Sedangkan unsur fosfor juga berperan sehingga dapat berfosintes dengan baik dan menghasilkan fotositat sehingga dapat meningkatkan pertumbuhan (Tisdale, dkk., 1985). 


\section{f. Berat Kering Akar}

Tabel 9

HASIL PENIMBANGAN BERAT KERING AKAR (GRAM) TANAMAN BAYAM PADA AKHIR MINGGU KE 3

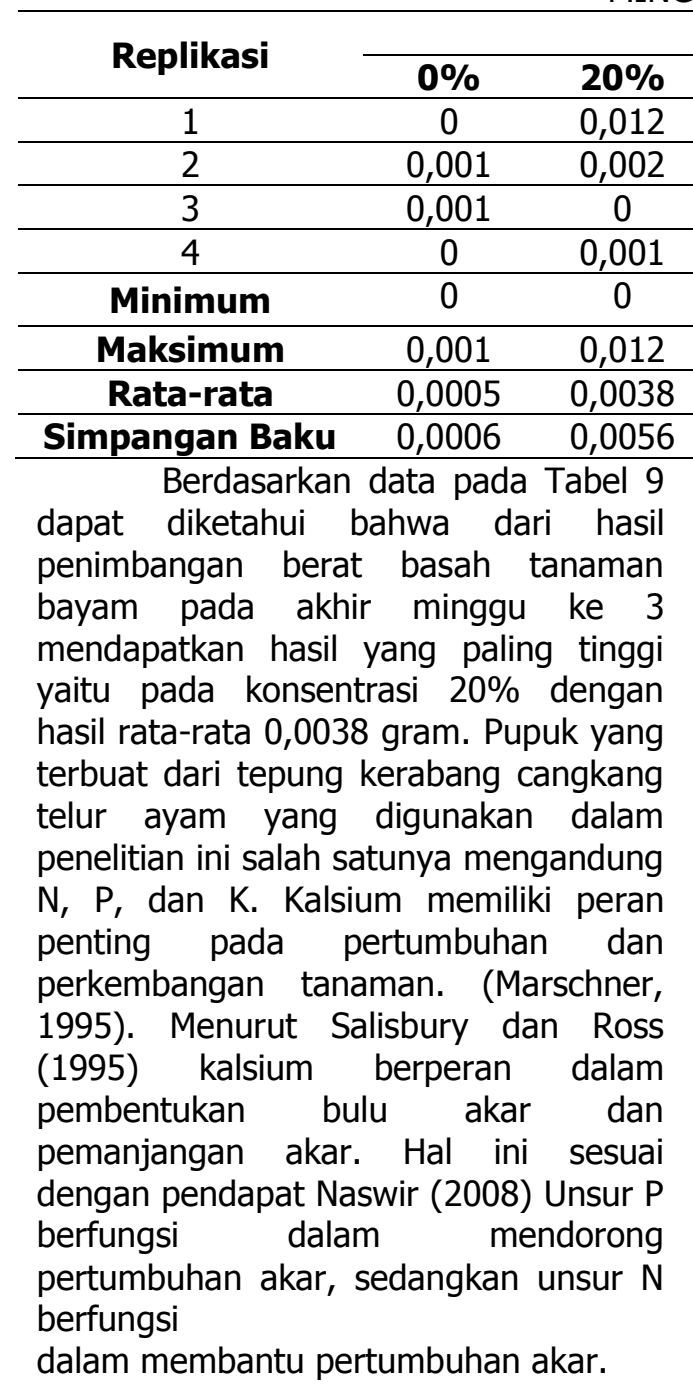

\section{KESIMPULAN}

1. Hasil pengukuran laboratorium untuk kandungan unsur hara $\mathrm{N}, \mathrm{P}$, dan $\mathrm{K}$ pada pemanfaatan cangkang telur ayam broiler sebagai tepung kerabang untuk meningkatkan unsur hara pada tanaman bayam dengan konsentrasi $0 \%$ (kontrol), $20 \%$, 25\%, 30\%, 35\%,dan $40 \%$ mengalami peningkatan. Seiring meningkatnya dosis juga meningkat pula hasil unsur hara $\mathrm{N}, \mathrm{P}, \mathrm{K}$.

2. Hasil pengukuran suhu udara pada ruangan penelitian yang dilakukan Konsentrasi

$\mathbf{2 5 \%} \quad 30 \% \quad 35 \% \quad 40 \%$

$\begin{array}{cccc}0,001 & 0,001 & 0,001 & 0\end{array}$

$\begin{array}{cccc}0,008 & 0,006 & 0,001 & 0,002 \\ 0,001 & 0 & 0,003 & 0,001\end{array}$

$\begin{array}{cccc}0,002 & 0 & 0 & 0,003\end{array}$

0,001

$\begin{array}{rrr}0 & 0 & 0\end{array}$

$\begin{array}{llll}0,008 & 0,006 & 0,003 & 0,003\end{array}$

$\begin{array}{llll}0,008 & 0,006 & 0,003 & 0,003 \\ 0,003 & 0,0018 & 0,0013 & 0,0015\end{array}$

$\begin{array}{llll}0,0037 & 0,0029 & 0,0013 & 0,0013\end{array}$

selama 3 minggu suhu dengan rata-rata $29,6^{\circ} \mathrm{C}$ dan hasil kelembaban dengan rata-rata $81,3 \%$.

3. Hasil pengukuran $\mathrm{pH}$ tanah pada pertumbuhan tanaman bayam dengan perlakuan konsentrasi $0 \%$ (kontrol) mendapatkan nilai ratarata 6 , konsentrasi $20 \%$ nilai ratarata 7 , konsentrasi $25 \%$ nilai ratarata 6,5 , konsentrasi $30 \%$ nilai rata-rata 6,5 , konsentrasi $35 \%$ nilai rata-rata 6,25 , dan konsentrasi $40 \%$ nilai rata-rata 6,25 .

4. Hasil pengukuran pada tanaman bayam dengan konsentrasi $0 \%$ (kontrol), 20\%, 25\%, 30\%, $35 \%$,dan $40 \%$ yaitu :

a. Rata-rata tinggi tanaman bayam adalah 3,$6 ; 7,25 ; 3,9 ; 3,9 ; 3,08$; dan 3,3.

b. Rata-rata jumlah daun pada tanaman bayam adalah 2,75; 3,$75 ; 2,5 ; 2,5 ; 2,5 ;$ dan 2,5 .

c. Rata-rata berat basah tanaman bayam adalah 0,013; 0,039; 0,$016 ; 0,016 ; 0,01$; dan 0,011.

d. Rata-rata berat basah akar pada tanaman bayam adalah 0,0043; 0,02; 0,0053; 0,0058; 0,0038; dan 0,0045 .

e. Rata-rata berat kering tanaman bayam adalah 0,0013; 0,005; 0,0025; 0,0018; 0,001; dan 0,0018 . 
f. Rata-rata berat kering akar pada tanaman bayam adalah 0,0005; 0,$0038 ; 0,003 ; 0,0018 ; 0,0018$; 0,0013; dan 0,0015.

5. Ada perbedaan dosis berat tepung kerabang cangkang telur terhadap pertumbuhan tanaman bayam selama 3 minggu dengan variasi konsentrasi $0 \%$ (kontrol), 20\%, $25 \%$, 30\%, 35\%,dan $40 \%$.

\section{SARAN}

1. Diperlukan penelitian lebih lanjut untuk mengetahui kebutuhan pokok unsur hara untuk pertumbuhan generatif tanaman bayam.

2. Diperlukan penelitian lebih lanjut mengenai penggunaan pupuk tepung kerabang cangkang telur dengan konsentrasi yang lebih rendah dari dosis yang telah digunakan pada penelitian ini (5\%, 10\%,15\%, dan 20\%).

3. Perlu dilakukan penelitian dengan menggunakan waktu pengamatan lebih dari 3 minggu.

4. Perawatan pada tanaman bayam harus memiliki perlakuan yang sama antara konsentrasi $0 \%$ (kontrol), 20\%, 25\%, 30\%, 35\%, $40 \%$ dan pengulangan.

\section{DAFTAR PUSTAKA}

Dianita, R., L. Abdullah. 2011. Effect of Nitrogen Fertilizer on Growth Characteristics and Productivity of Creeping Forage Plants for TreePasture Integrated System. Jurnal of Agricultural Science and Technology A 1. 1118-1121.

Emi, Eka Lokaria, Harmoko, 2014. (Pengaruh Pupuk Serbuk Cangkang Telur Ayam Ras Terhadap Pertumbuhan Tanaman Sawi Caisim (Brassica Juncea L). Sumatera Selatan:STKIP-PGRI Lubuklinggu.

Hardjowigeno, S. 2007. Ilmu Tanah Akademik Presindo. Jakarta: Akademika Pressindo.

Haryanto, E., Tina S. E., Rahayu, dan Hendro S. (2003). Sawi dan selada.

(http://books.google.co.id/books?i $\mathrm{d}=4$ iyG6pWqd5sC\&pg $=$ PA9\&dq $=\mathrm{s}$ awi+caisim+(Brassica+juncea)\&hl $=$ id\&sa $=X \&$ ei $=$ xgpgUaaKEorMrQe LmYGICg\&ved $=0 \mathrm{CF}$

UQ6AEwCA\# $v=$ onepage $\& q \& f=$ fals e. Diakses pada 20 Mei 2019).

Irma, Wirdati. 2015. Pengaruh Pemberian Timbal (Pb) Terhadap Morfologi Daun Bayam (Amaranthus Tricolor L.) Dalam Skala Laboratorium. Riau: Jurnal Ipteks Terapan Program Studi Bilogi Fak.MIPA dan Kesehatan Universitas Muhammadiyah Riau.

Isniati. 2009. Pengaruh Penambahan Tepung Kerabang (Cangkang Telur) Dalam Proses Pengomposan Sampah Organik. Jurnal. SAINSTEK Vol. XII, No. 1, September 2009.

Jovita, Deborah. 2018. Analisis Unsur Makro (K, Ca, Mg) Mikro (Fe, Zn, Cu) Pada Lahan Pertanian Dengan Metode Inductively Coupled Plasma Optical Emission Spectrofotometry (Icp-Oes). Lampung: fakultas matematika dan ilmu pengetahuan alam universitas lampung bandar lampung.

Marschner, H. 1995. Mineral Nutrition of Higher Plants. Second Edition. Acad. Press. London.

Naswir. 2008. Pemanfaatan Urine Sapi yang Difermentasi Sebagai Nutrisi Tanaman.

naswirauoei@yahoo.com. Diakses pada tanggal 22 April 2019.

Novizan. 2005. Petunjuk Pemupukan yang Efektif. Agromedia Pustaka. Jakarta.

Nurjanah, dkk. 2017. Pengaruh Pemberian Tepung Cangkang Telur Ayam (Gallus Gallus Domesticus) Terhadap Pertumbuhan Tanaman Caisim (Brassica Juncea L.) Dan Sumbangannya Pada Pembelajaran Biologi SMA. Sumatera Selatan:Program Studi Pendidikan Biologi FKIP Universitas Sriwijaya.

Nurshanti, F. D. 2009. Pengaruh Pemberian Pupuk Organik 
Terhadap Pertumbuhan dan Hasil Tanaman Sawi Caisim (Brasicca juncea L.). Jurnal Agrobisnis. 1 (1), 89-98.

Salisbury, F.B., dan Cleon.W.Ross., 1995. Fisiologi tumbuhan, jilid 1, edisi 4, diterjemahkan oleh Diah R.L. dan Sumaryono, ITB, Bandung.

Sitompul, S. M. \& Guritno, B. 1995. Analisis pertumbuhan tanaman. Yogyakarta: UGM Press.

Suhartina, Purwantoro, Abdullah Taufiq, Novita Nugrahaeni. 2013. Panduan Roguing Tanaman dan Pemeriksaan Benih Kedelai, ISBN: 978-60295497-3-7.
Sumarni E, Suroso, A Margiwiyatno. 2007. Pendugaan hasil tanaman bayam (Amaranthus tricolor L.) secara hidroponik dengan jaringan syaraf tiruan ANN. J Agrin. 11(1): 1-9Wahyuni, Eka P. 2018. Mempelajari Karakteristik Pengeringan Bayam Hijau (Amaranthus Tricolor L.). Lampung : Fakultas Pertanian Universitas Lampung Bandarlampung.

Sutejo, M.M., 2002. Pupuk Dan Cara Pemupukan. Jakarta:Rineka Cipta.

Tisdale, S. L., W. I. Nelson and J. D. Beston. 1985. Soil Fertyility and Fertilizer Fourth Edition. Mc Milan Publishing co. New York. 745 p. 